\title{
SQUAMOUS CELL CARCINOMA OF THE PROSTATE: A CASE REPORT
}

Vinay S. Kundargi ${ }^{1}$, Ashok N. Biradar ${ }^{2}$, Siddangouda B. Patil ${ }^{3}$, Nikhil A. Patil ${ }^{4}$, Anup S. Desai ${ }^{5}$

\section{HOW TO CITE THIS ARTICLE:}

Vinay S. Kundargi, Ashok N. Biradar, Siddangouda B. Patil, Nikhil A. Patil, Anup S. Desai. "Squamous Cell Carcinoma of the Prostate: A Case Report". Journal of Evolution of Medical and Dental Sciences 2014; Vol. 3, Issue 29, July 21; Page: 8019-8022, DOI: 10.14260/jemds/2014/3005

ABSTRACT: Carcinoma of the prostate gland is the most frequent malignant tumor affecting male population. While the large majority of tumors are represented by adenocarcinoma, pure squamous cell carcinoma (SCC) comprises only $0.5-1 \%$ of all prostate neoplastic lesions. We herein report a case of pure squamous cell carcinoma of the prostate. A 60 years old male presented with history of lower urinary tract symptoms. Patient was subsequently subjected for transurethral resection of prostate and histopathology of prostatic chips showed SCC of the prostate.

KEYWORDS: adenocarcinoma, pure squamous cell carcinoma, transurethral resection.

INTRODUCTION: Primary squamous cell carcinoma (SCC) of the prostate gland is a rare (0.5-1\%) condition, deemed rather more malignant than the ordinary adenocarcinoma and resistant to the usual therapy for prostate cancer. It is characterized by a high degree of malignancy, commonly metastasizing to the bone (mainly with osteolytic lesions), liver and lungs with a median survival time of 14 months. This is a report of a case controlled by a synergistic combination of chemotherapy and radiotherapy.

CASE REPORT: We herein report on a case of pure squamous cell carcinoma of the prostate. A 68 years old male presented with history of lower urinary tract symptoms. Physical examination was unremarkable. Per abdomen was normal, digital rectal examination shows grade 2 benign enlargement of prostate with no signs of malignancy. Serum prostate specific antigen (PSA) concentration was in the normal range $(1.1 \mathrm{ng} / \mathrm{ml})$.

Patient was subsequently subjected for transurethral resection of prostate and histopathology of prostatic chips showed SCC of the prostate. Serum SCC antigen was $9.96 \mathrm{ng} / \mathrm{ml}$ (normal 0-1.5 ng/ml). No squamous metaplasia, transitional cell carcinomatous or adenocarcinomatous components were noticed. In view of patient's age and survival rate he was offered chemoradiation.

The patient was given 3 courses of chemotherapy (CT) with cisplatin (CDDP) $75 \mathrm{mg} / \mathrm{m} 2$ on day 1 and continuous infusion 5 -fluorouracil (5-FU) $750 \mathrm{mg} / \mathrm{m} 2$ on day 1 to 5 . He subsequently underwent a full-course of radiation therapy (RT) using linear accelerator (18 MV photons), with a conventional four-field box technique up to $46 \mathrm{~Gy}$ to the whole pelvis followed by a boost dose to the prostate bed of 20 Gy and by an adjunctive dose of 6 Gy to the prostate gland ( 72 Gy in total).

Patient has completed 18 months of his treatment and is regular in his follow up. Patient is voiding well with a good improvement in symptom score and uroflowmetry showing max flow of 16 $\mathrm{ml} / \mathrm{second}$. 
DISCUSSION: Squamous metaplasia is known for occurring in the prostate in chronic prostatitis, around prostatic infarcts and after estrogen therapy or radiation therapy ${ }^{1}$. In some cases, this has been misdiagnosed as SCC. Mott suggested the strict criteria for the diagnosis of primary prostatic SCC:

(i) A clearly malignant neoplasm as judged by invasion, disordered growth and cellular anaplasia;

(ii) Definite squamous features of keratinization, squamous pearls and/or numerous distinct intercellular bridges;

(iii) A lack of any glandular or acinar pattern;

(iv) No prior estrogen therapy; and

(v) An absence of primary squamous cancer elsewhere, particularly in the bladder.

Primary SCC of the prostate is very rare, comprising only $0.5-1 \%$ of all prostatic carcinomas. ${ }^{2}$ Approximately 50 cases have been reported in the English literature and 10 cases, including ours, are recorded in Japan. ${ }^{3}$

The histogenesis of this cancer has not been clarified. Two chief origins are presumed: the basal cells of prostatic acini and the transitional epithelia lining major ducts. Theoretically, the tumor that develops from the former may resemble common prostatic adenocarcinoma and would be sex hormone responsive. ${ }^{4}$ Usual presentation is bladder outlet obstruction. Consistency of the prostate is variable and not always hard. Different from primary adenocarcinoma, serum PSA and acid phosphatase levels are within normal limits, even with metastasis.

Therefore, some cases have been preoperatively misdiagnosed as benign prostatic hyperplasia (BPH). ${ }^{5}$ Instead, SCC antigen in the blood is elevated and corresponds to the treatment effect or progression of squamous cancer of the prostate. ${ }^{6}$ Squamous cell carcinoma of the prostate is aggressive and has a worse prognosis than ordinary adenocarcinoma. This cancer is independent of androgen and early metastatic spread is not uncommon.

The average post-diagnosis survival is estimated to be 14 months, although multiple treatment modalities, including radical operation, have been used. Chemotherapeutic agents, such as CDDP, bleomycin (BLM), PEP and methotrexate, have been tried, based on squamous head and neck carcinoma. Nevertheless, the results of therapy indicate that the treatments do not seem to be of value. In general, radiation therapy seems ineffective. In Japan, the longest survivor of this cancer, who had a tiny SCC suburethrally, has been free of recurrence for 6 years since patient underwent prostatectomy for a BPH.7

Uchibayashi et al. controlled tumor progression for 21 months after transurethral prostatectomy by means of local irradiation, intravenous administration of BLM and intra-arterial administration of CDDP. However, a complete cure is not expected unless the disease is organ confined and radical extirpation is performed. ${ }^{8}$

CONCLUSION: Squamous differentiation in prostate cancer is uncommon, often but not necessarily arising in the setting of prior hormone or radiation therapy, and is associated with a poor prognosis. 


\section{REFERENCES:}

1. Sieracki JC. Epidermoid carcinoma of the human prostate: Report of three cases. Lab Invest. 1955; 4: 232-40.

2. Mott LJM. Squamous cell carcinoma of the prostate: Report of 2 cases and review of the literature. J Urol.1979; 121: 833-5.

3. Moskovitz B, Munichor M, Bolkier M, Livne PM. Squamous cell carcinoma of the prostate. Urol Int.1993; 51: 181-3.

4. Nancy AL, Wiener JS, Walther PJ, Paulson DF, Anderson EE. Squamous cell carcinoma of the prostate: 2 cases of a rare malignancy and review of the literature. J Urol. 1993; 149: 137-9.

5. Sarma DP, Weilbaecher TG, Moon TD. Squamous cell carcinoma of the prostate. Urology 1991; 37: $260-2$.

6. Okamoto T, Ogiu K, Sato M et al. Primary squamous cell carcinoma of the prostate: A case report. Hinyokika Kiyo 1996; 42: 67-70 (in Japanese).

7. Uchibayashi T, Hisazumi H, Hasegawa M et al. Squamous cell carcinoma of the prostate. Scand J Urol Nephrol. 1996; 33: 223-4.

8. Masuda H, Yamada T, Nagahama K, Nagamatu H, Negishi T. Primary squamous cell carcinoma of the prostate: A case report. Jpn J Urol Surg. 1992; 5: 519-21.

Fig. 1: Histological section of the prostate showing invasive growth of SCC Haematoxylin and eosin, $\times 200$.

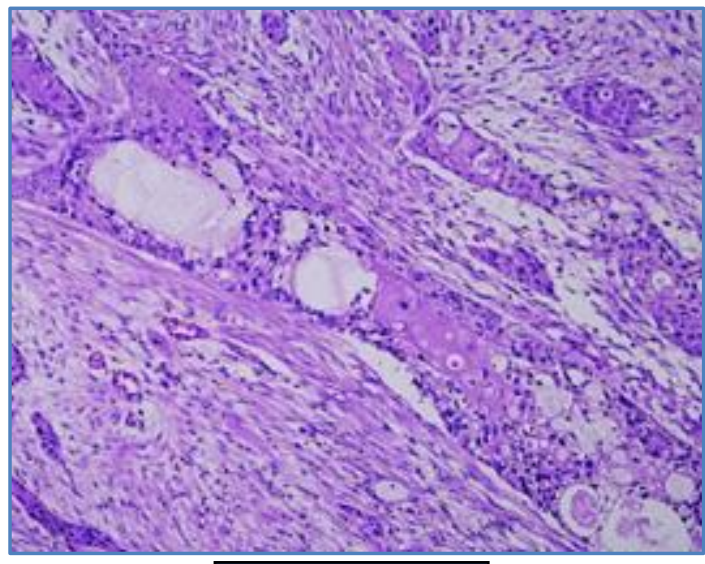

Figure 1 


\section{CASE REPORT}

\section{AUTHORS:}

1. Vinay S. Kundargi

2. Ashok N. Biradar

3. Siddangouda B. Patil

4. Nikhil A. Patil

5. Anup S. Desai

\section{PARTICULARS OF CONTRIBUTORS:}

1. Professor, Department of Urology, Shri B. M. Patil Medical College and Research Centre, Bijapur.

2. Senior Resident, Department of Urology, Shri B. M. Patil Medical College and Research Centre, Bijapur.

3. Professor and HOD, Department of Urology, Shri B. M. Patil Medical College and Research Centre, Bijapur.

4. Senior Resident, Department of Urology, Shri B. M. Patil Medical College and Research Centre, Bijapur.
5. Senior Resident, Department of Urology, Shri B. M. Patil Medical College and Research Centre, Bijapur.

\section{NAME ADDRESS EMAIL ID OF THE CORRESPONDING AUTHOR:}

Dr. Vinay S. Kundargi, Department of Urology, Shri B. M. Patil Medical College, Bijapur.

Email: vinayuro@rediffmail.com

Date of Submission: 22/04/2014. Date of Peer Review: 23/04/2014. Date of Acceptance: 09/07/2014. Date of Publishing: 16/07/2014. 